\title{
Haig KHATCHADOURIAN
}

1925 - 2016

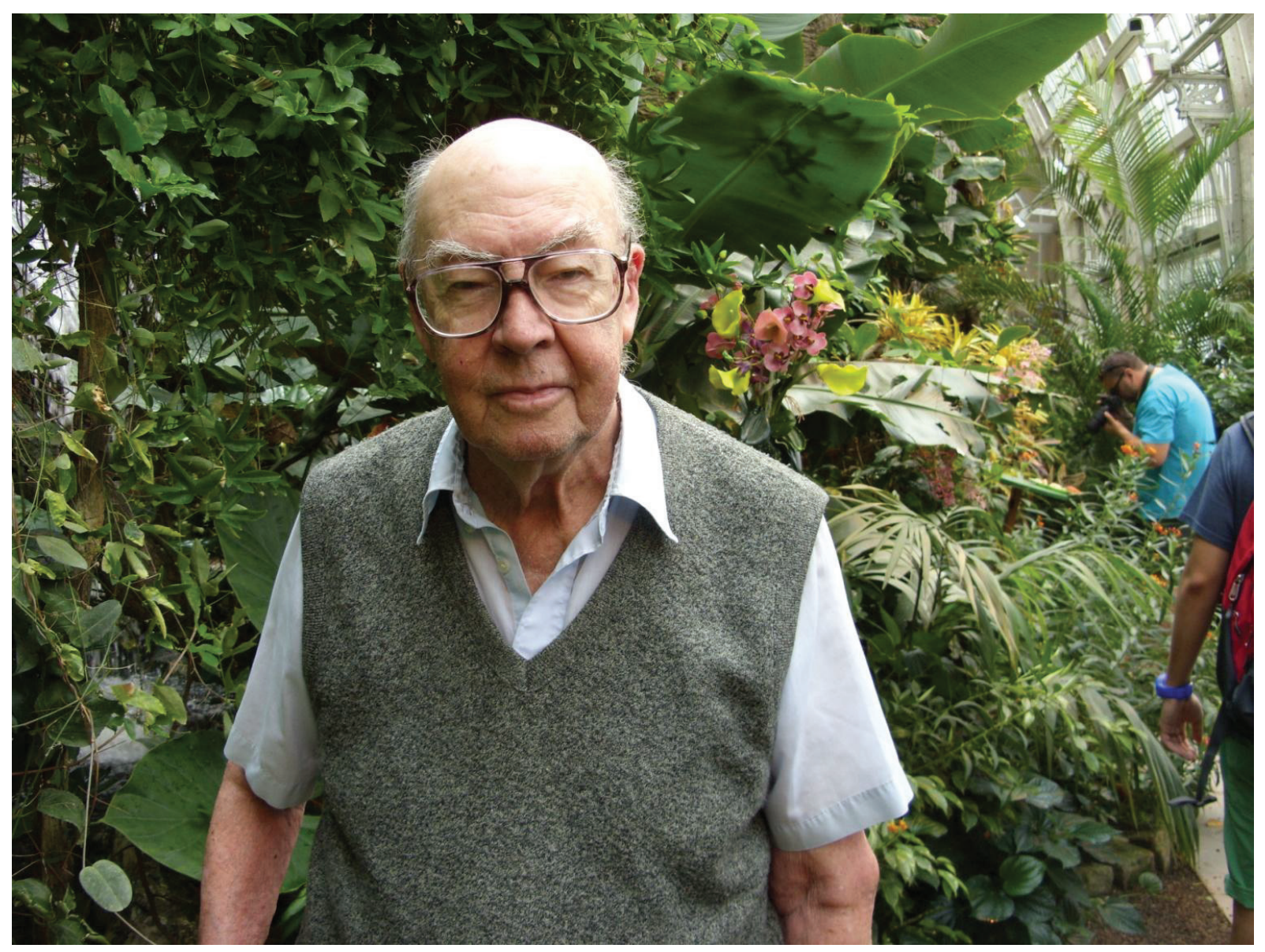

In 2016, the world of Philosophy lost a tremendous and tireless scholar with the passing of Professor Haig Khatchadourian.

Haig Khatchadourian, Professor Emeritus of Philosophy at the University of WisconsinMilwaukee from the late 1960's until 1994, was educated at the American University of Beirut (B.A. and M.A.) and at Duke University (Ph.D.). He also taught at the American University of Beirut (1948-49, 1956-68), Melkonian Educational Institute, Nicosia, Cyprus (1950-1951), Haigazian College, Beirut (1951-52), the University of Southern California (1968-69), and was a Visiting Professor at the University of Hawaii-Manoa (1976-77) and a Distinguished Visiting Professor at the University of New Mexico-Albuquerque (1978-79). His areas of specialization included: Aesthetics and Philosophy of the Arts, Ethics, Philosophy of Language, Political Philosophy, and Social Philosophy, among others. He was a member of learned societies and presented papers at international conferences from 1958 to 2007. He participated in the Harvard International Seminar (summer, 1962) and was a Liberal Arts Fellow in Philosophy and Law at Harvard Law School (1982-3). He received numerous honors and awards, including Outstanding Educators of America Award, 2,000 Intellectuals of the $20^{\text {th }}$ Century and 2,000 Outstanding Academics of the $21^{\text {st }}$ Century. He published 19 books and at least 94 articles. His most recent book is How to Do Things with Silence. (deGruyter, 2015) 
Unluckily Khatchadourian was not widely known amongst Armenian scientific society. International Academy for Philosophy (IAPh) established by Academician Georg Brutian has a great mission to serve and develop the international world of philosophy through connecting philosophers from all over the world. Besides this it has also done a great job of bringing together Armenian philosophers from different parts of the world, with the vivid example of us getting to know Professor Haig Khachadourian, who was an honorable member of IAPh.

American-Armenian professor was planning to visit Armenia with his daughter in summer 2016, but his death in February 2016 left his great wish of visiting Armenia and his beloved friend Georg Brutian unrealized. Before his death Professor Khachadourian inscribed a copy of his last book How to Do Things with Silence (de Gruyter, 2015) for Georg Brutian, which is interestingly enough the last handwritten writing by him. As he did not manage to bring it with him to Armenia in summer 2016, his daughter who's been communicating with the Philosophy and Logic department at Pedagogical university after Khachatur Abovyan sent it to the department. A memorial bench has been established at the American University of Beirut, which was one of Khachadourian's true wishes.

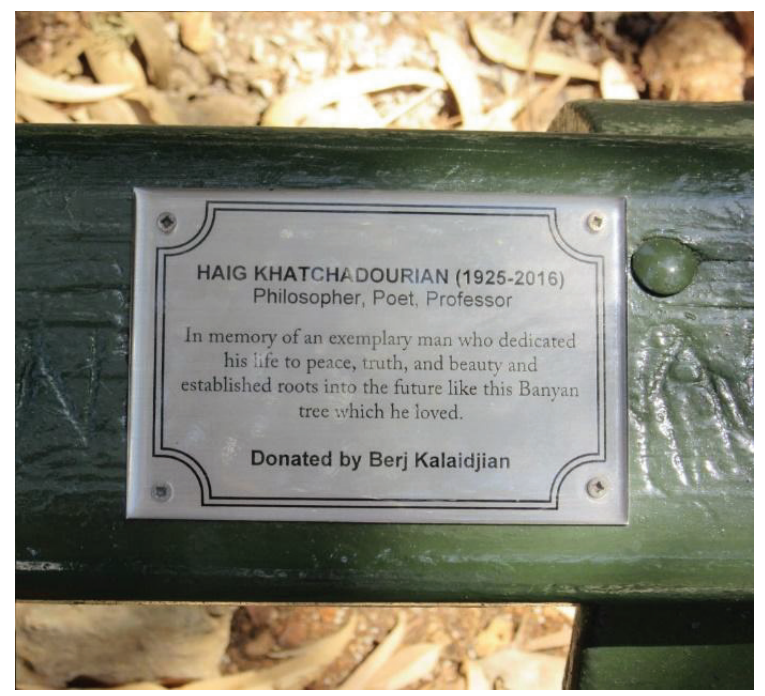

Haig Khatchadourian's wife Arpine Khatchadourian was an established philosopher as well. Arpiné Khatchadourian (1925-2012) completed her primary education at Sts. Tarkmanchatz, the Armenian St. James Patriarchate School, and her secondary education at a British High School, both in Jerusalem, Palestine during the British Mandate. After graduating, she taught at Sts. Tarkmanchatz for eight years. In 1950, she married Haig Khatchadourian. The following year, she taught at the Melkonian Institute in Nicosia, Cyprus. The couple then resided in Beirut, Lebanon, where she received her Associate in Arts Degree at the Beirut College for Women in 1953 and taught for several years at the AGBU TarouhieHagopian Secondary School in Beirut. After she and her family emigrated to the United States in 1967, she continued her studies and received a Bachelor of Arts degree summa cum laude and Master of Arts in Comparative Literature, with Honors, and completed all work for her Ph.D. in English and American Literature at the University of Wisconsin-Milwaukee, except for her dissertation. While a student, she was inducted into Phi 
Kappa Phi, a national academic honor society. She taught in both the UW-Milwaukee Department of Comparative Literature and English Department. She also taught "Armenian: An Uncommonly Taught Language" in the UW-Milwaukee Linguistics Department for several years. She received a Teaching Excellence Award from the UW-Milwaukee English Department in the 198586 academic year. Khatchadourian retired in 1997 after 47 years of teaching that included primary, secondary, high school, and university instruction. The Armenian language and literature, world mythology, and comparative literature were her vocation and avocation. David of Sas- soun: An Introduction to the Study of the Armenian Epic is based on original research material. Her essay, "The Oath and the Curse as a Source of Action in David of Sassoun" was published in David of Sassoun: Critical Studies on the Armenian Epic, by DIckran Kouymjian and Barlow Der Mugrdechian in 2013 by The Press at California State University, Fresno.

Professor Khachadourian's academic career, intelligence, and deep commitments to the study of philosophy undeniably had significant contribution to the world of philosophy. Our editorial board hopes that Armenian philosophical society will get to better know his scientific heritage.

Hasmik HOVHANNISYAN

Doctor of Sciences (in Philosophy), General Scientific Secretary of the International Academy for Philosophy (IAPh) 